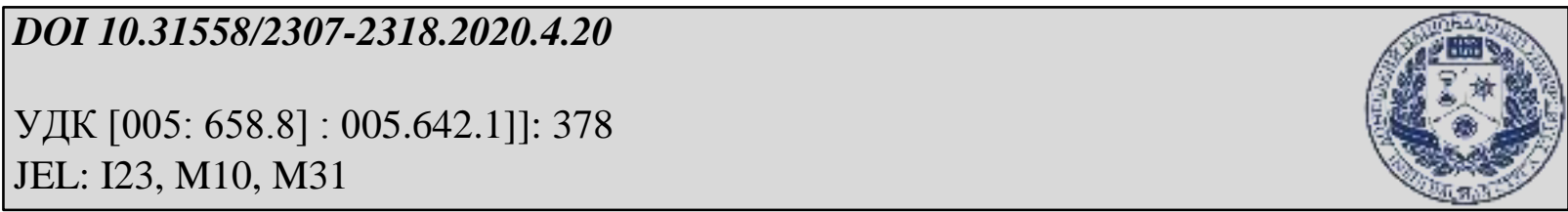

Банзелюк I.В.

аспірантка, Донецький національний університет імені Василя Стуса

ORCID: 0000-0002-0266-0569

i.snisarchuk@donnu.edu.ua

\title{
КОНЦЕПЦІЯ РОЗВИТКУ МАРКЕТИНГОВОГО ПОТЕНЦАЛУ ЗАКЛАДІВ ВИЩОЇ ОСВІТИ НА ЗАСАДАХ БЕНЧМАРКІНГУ
}

У статті обгрунтовано концептуальні положення розвитку маркетингового потенціалу ЗВО на засадах бенчмаркінгу. Окреслено складові розробленої концепції. Запропоновано розвиток маркетингового потенціалу ЗВО на рівнях його формування, а саме на нанорівні, мікрорівні, мезорівні та макрорівні та визначено завдання реалізації концепції на кожному 3 рівнів. Визначено ключові функції, які покладаються на систему розвитку маркетингового потенціалу ЗВО при використанні бенчмаркінгу як інструменту розвитку. Запропоновано здійснювати їх поділ на класичні функції та функції бенчмаркінгу. Розроблено комплексний механізм розвитку маркетингового потенціалу 3ВО на засадах бенчмаркінгу, який дозволить досягти мети запропонованою концепції за рахунок синергії трьох складових: організаційного, фінансово-економічного та гендерно-поведінкового механізму. На підставі проведеного дослідження окреслено особливості концепції розвитку маркетингового потенціалу ЗВО на засадах бенчмаркінгу та зазначено очікувані результати від іiі реалізації в освітньому просторі.

Ключові слова: маркетинговий потенціал, розвиток, заклад вищої освіти, бенчмаркінг, рівні розвитку, концепція розвитку маркетингового потенціалу.

Рис. -3 , Табл. -2 , Літ. -20.

Постановка проблеми. Залежність економічного розвитку будь-якої країни від кваліфікованих кадрів беззаперечно пов'язується 3 конкурентоспроможністю закладів вищої освіти (3ВО), що виступають в якості осередку формування потенціалу як національного багатства. Надання переваги абітуріснтами закордонним ЗВО або бажання здобувати в них освіту свідчить про невміння або наявність проблем у певних суб'єктів освітнього простору використовувати власний маркетинговий потенціал. Підвищення статусу українських ЗВО та популяризація їх серед абітурієнтів інших країн в деякій мірі дозволить запобігти інтелектуальній еміграції та створити умови для залучення більшої кількості іноземних студентів. Виконання завдань 3 підвищення конкурентоспроможності ЗВО та освітнього простору загалом можливо забезпечити, здійснюючи розвиток маркетингового потенціалу ЗВО з використанням бенчмаркінгу як базису прийняття раціональних рішень.

Аналіз останніх досліджень та публікацій. Внесок в теорію та методологію розвитку потенціалу організацій, в тому числі маркетингового, здійснили наступні науковці: I. Поліщук, 3. Бараник та О. Карабанова, О. Мельничук, О. Чмельова та О. Татарчук, Т. Халімон Т. та інші.

Питанню дослідження сутності бенчмаркінгу та його використання в діяльності організацій присвячено праці таких вчених, як Р.Кемп, Л. Босіді, Р. Чаран, Л. Прус, 
I.Ахновська, Д. Попович, О. Тарнавська, О.Пащенко, Г. Охрименко, I. Аренкова, С. Багієва, Т. Голубєва, Т. Данілова, Н. Казакова, С. Ліфанова та інших.

Однак, теоретичні та практичні засади використання бенчмаркінгу для потреб розвитку маркетингового потенціалу ЗВО недостатньо висвітлені в сучасній науковій літературі, у зв'язку 3 чим особливо важливим питанням постає формування концептуальних положень розвитку маркетингового потенціалу ЗВО на засадах бенчмаркінгу, чим і обумовлено актуальність теми дослідження.

Метою дослідження $\epsilon$ обгрунтування концепції розвитку маркетингового потенціалу ЗВО на засадах бенчмаркінгу.

Викладення основного матеріалу. Учені наголошують, що рівень розвитку освітньої та наукової сфери визначає стан освітнього потенціалу країни, ефективне використання якого відображається у здатності генерувати нові ідеї та використовувати ïx у процесі забезпечення економічного зростання [1,c.205]. На варті економічного зростання та підвищення конкурентоспроможності вітчизняних 3ВО стоїть маркетинговий потенціал як базис розвитку та критерій відповідності сучасним вимогам економічного середовища. Для створення теоретичного підгрунтя розвитку маркетингового потенціалу ЗВО необхідним $є$ розробка основних положень такого розвитку, які можна оформити в концепцію.

Передумовою розробки концепції розвитку маркетингового потенціалу ЗВО на засадах бенчмаркінгу є дослідження сутності поняття «концепція» та необхідності іiі розробки. Проведені дослідження вказують на те, що зміст поняття «концепція» розкривається в сучасній літературі з двох підходів: класичного, що базується на словниках, та наукового - як результат досліджень науковців (Табл.1).

Таблиця 1

Погляди науковців на визначення поняття «концепція»

\begin{tabular}{|c|c|}
\hline Класичний підхід & Науковий підхід \\
\hline $\begin{array}{l}\text { Концепція (англ. - conception) - комплекс основних } \\
\text { ідей, принципів, правил, які розкривають сутність та } \\
\text { взаємозв'язки явища або системи, дозволяють } \\
\text { визначити систему показників, факторів та умов, які } \\
\text { сприяють вирішенню проблеми, формуванню } \\
\text { стратегії фірми, встановленню правил поведінки } \\
\text { особи; система ключових положень, що досить } \\
\text { повно, цілісно і всебічно розкривають сутність, зміст } \\
\text { і особливості досліджуваного явища, його існування } \\
\text { в дійсності [2] }\end{array}$ & $\begin{array}{l}\text { Система взаємопов’язаних і логічно вибудованих } \\
\text { поглядів } \\
\text { (задумів, ідей) відносно будь-якого явища або } \\
\text { процесу (об’єкта дослідження), які випливають } \\
\text { один } 3 \\
\text { одного, спрямовуються на вирішення проблем і } \\
\text { завдань щодо досягнення цілей (результату від } \\
\text { використання концепції) шляхом дотримання } \\
\text { принципів, } \quad \text { застосування } \\
\text { інструментів відповідних } \\
\text { (способів, методів, планів), мають наукове і } \\
\text { практичне значення [3, с.94-95] }\end{array}$ \\
\hline $\begin{array}{l}\text { Концепція (від латинського сопсерtio - розуміння, } \\
\text { система) - певний спосіб розуміння, тлумачення } \\
\text { будь-яких явищ, основний погляд, керівна ідея для їх } \\
\text { висвітлення; провідний задум, конструктивний } \\
\text { принцип різних видів діяльності [4] }\end{array}$ & $\begin{array}{l}\text { Управлінська конструкцію, що містить загальне } \\
\text { системне уявлення } \\
\text { шляхів переходу від поточного положення } \\
\text { об’єкта управління до бажаного [5,c. 94-95] }\end{array}$ \\
\hline $\begin{array}{l}\text { Концепція, також концепт (лат. conceptio - } \\
\text { розуміння) - система поглядів на ті чи інші явища, } \\
\text { процеси; спосіб розуміння, трактування певних } \\
\text { явищ, подій; ідея певної теорії». Термін вживають } \\
\text { також для позначення головного задуму в науковій, } \\
\text { художній, політичній та інших видах діяльності } \\
\text { людини [6] }\end{array}$ & $\begin{array}{l}\text { Концепція - це свого роду узагальнене розуміння } \\
\text { окремих процесів, яке комплексно характеризує } \\
\text { його і сприяє } \\
\text { досягненню цілей чи вирішенню проблем [7, } \\
\text { с.72] }\end{array}$ \\
\hline
\end{tabular}

* узагальнено автором 
Отже, концепція виступає певною філософією роботи, підгрунтям якої є визначені принципи, методи, ключові положення, очікувані результати та особливості роботи кожної організації. На нашу думку, влучним $є$ трактування концепції, яке запропонували М. Корваленко та М. Сікалоз точки зору конструкції, що дозволяє здійснити перехід від поточних показників діяльності організації до цільових значень. Кожний розглянутий підхід до визначення сутності поняття «концепції» вказує на те, що основною змістовною характеристикою виступає погляд науковця на певну проблематику, який на базі знань та розумових процесів репрезентується в концептуальні положення за окремим явищем або проблемою.

Враховуючи різні підходи до трактування концепції, пропонуємо авторське визначення поняття «концепція розвитку маркетингового потенціалу ЗВО на засадах бенчмаркінгу» як логічно побудований задум досягнення цілей розвитку маркетингового потенціалу закладів вищої освіти, який розкриває основну ідею щодо вирішення поставлених завдань.

Так, метою концепції розвитку маркетингового потенціалу ЗВО на засадах бенчмаркінгу $є$ збалансований розвиток маркетингового потенціалу ЗВО для збільшення чисельності абітурієнтів 3 метою підвищення рівня конкурентоспроможності на ринку освітніх послуг.

Надання переваги чисельності абітурієнтів, а не студентів в результаті реалізації концепції як критерію іï ефективності обумовлюється тим, що ЗВО буде здатен вибирати найкращих студентів 3 числа вступників для формування сильного конкурентного становища на ринку освітніх послуг.

Запропонована концепція базується на гіпотезі, що ефективно розвивати маркетинговий потенціал 3ВО можливо при одночасному впливі на об'єкт розвитку всередині організації та зі сторони стейкхолдерів, наприклад держави та органів виконавчої влади на місцях.

Таким чином, структура концепції окреслює рівні розвитку маркетингового потенціалу для досягнення найбільш ефективних результатів управління. Отже, пропонуємо розрізняти рівні розвитку маркетингового потенціалу ЗВО [8], а саме: нанорівень, мікрорівень, мезорівень та макрорівень.

Нанорівень (особистісний) рівень розвитку передбачає акцентування уваги на окремій особі як носієві маркетингового потенціалу та підгрунті для формування наступних за масштабами рівнів.

Мікрорівень (організаційний) рівень розвитку фокусується на використанні професійних якостей персоналу у поєднанні з наявними ресурсами і можливостями, якими володіє ЗВО, що в результаті дозволить досягти бажаного економічного ефекту.

Також на зазначеному рівні відбувається всебічний розвиток ЗВО та пошук нових уособлень маркетингового потенціалу, що значно доповнює вже наявний арсенал. Мікрорівень $є$ важливою ланкою розвитку маркетингового потенціалу ЗВО, адже, в результаті, впливає на формування регіонального та галузевого маркетингового потенціалу.

Сукупність маркетингових потенціалів 3ВО певної території або галузі формують третій рівень - мезорівень. Саме мезорівень маркетингового потенціалу характеризує особистий внесок кожного ЗВО у розвиток освітнього середовища певного регіону або галузі. Мезорівень маркетингового потенціалу є одним з факторів впливу на кількість абітурієнтів, міграцію робочої сили, рівень зайнятості населення та безробіття регіону. 
В результаті, розвиток маркетингового потенціалу ЗВО на мезорівні відбивається на макроекономічних показниках держави, що утворює четвертий рівень розвитку, а саме- макрорівень (національний).

Отже, можна стверджувати, що споживачем створеного ЗВО маркетингового потенціалу $є$ не тільки сам ЗВО, а й економіка в цілому, наприклад, в праці О. Дороніної [9] обгрунтовуються роль науки у підготовці студентів ЗВО як основного фактора створення компетентних працівників у всіх галузях економіки.

Досягненню мети концепції сприяють завдання зведені в групи відповідно до виділених рівнів розвитку маркетингового потенціалу ЗВО:

- на нанорівні: розвиток професійних компетенцій у студентів; розуміння поведінки споживача освітніх послуг; задоволення фізіологічних потреб студентів під час навчання; врахування потреб співробітників;

- на мікрорівні: еволюціонування та ефективне використання та власного потенціалу; збалансований розвиток всіх ключових ресурсів маркетингового потенціалу; швидка адаптація до будь-яких змін зовнішнього та внутрішнього середовища, особливо до вимог цільової аудиторії; використання в діяльності позитивного досвіду організацій-лідерів будь якої галузі економіки;

- на мезорівні та макрорівні: підвищення інтелектуального рівня нації та рівня конкурентоспроможності вітчизняної вищої освіти на міжнародному ринку освітніх послуг, досягнення рівномірного розвитку регіонів та країни загалом.

Об'єктом запропонованої концепції виступає розвиток маркетингового потенціалу 3ВО, який доцільно починати 3 визначення ключових ресурсів, які виступають головним уособленням напрямків використання маркетингового потенціалу в ЗВО. Для обгрунтування основних форм маркетингового потенціалу важливо розуміти його сутність та підходи до трактування.

В науковій літературі відсутня єдина думка науковців щодо сутності маркетингового потенціалу організацій, відповідно, чітке та прийняте науковою спільнотою трактування змісту маркетингового потенціалу 3ВО також відсутнє, що стало передумовою досліджень щодо розкриття сутності даного поняття.

Отже, проведене дослідження вказує на те, що найчастіше маркетинговий потенціал характеризують як позитивний фактор розвитку організації, наприклад, В.Іваненко та О. Ковальчук притримуються думки, що маркетинговий потенціал - це «здатність (спроможність) підприємства максимально використовувати наявні ресурси i можливості (внутрішні i зовнішні) в процесі маркетингової діяльності для забезпечення досягнення як стратегічних, так i поточних цілей при формуванні конкурентних переваг [10, с.75]».

Також, роль маркетингового потенціалу в підвищенні прибутковості підприємства розглядає Л. Маматова та зазначає, що «саме маркетинговий потенціал підприємства сприяє підвищенню іміджу (репутації) i отриманню суб'єктом господарювання додаткових конкурентних переваг, що дають змогу зміцнити його позиції на ринку, розширити сегмент (частку) ринку та покращити ставлення споживачів до продукції підприємства. Крім того, ефективний маркетинговий потенціал зумовить підвищення якості продукції та збільшення попиту, зростання показників фінансово-інвестиційного потенціалу й ефективності діяльності» [11; с. 145].

С. Кунєв та Є. Мальченков схильні до думки, що маркетинговий потенціал $€$ підсистемою економічного потенціалу підприємства, яка внаслідок використання 
ресурсів інших підсистем та залучених ресурсів підгалузей індустрії ставить на меті забезпечення конкурентоспроможності на цільовому сегменті ринку [12].

О. Родіонова розглядає маркетинговий потенціал як можливості та готовність маркетингової системи управляти попитом на пропоновані товари i послуги, використовуючи для цього наявні маркетингові ресурси та можливості бізнессередовища [13].

В. Баранчєєва та С. Стріжова виділили три підходи дослідження маркетингового потенціалу: циклічний, системний і діагностичний [14]. Ми погоджуємось 3 думкою авторів 3 приводу виділення циклічного підходу в дослідженні маркетингового потенціалу, але вважаємо, що важливо доповнити даний підхід наявністю циклічності у внутрішніх властивостях маркетингового потенціалу, як окремого явища в організації, a не явища, що супроводжує життєвий цикл товару/послуги. В той самий час, ми вважаємо, що концепція циклічності не повною мірою охоплює сутність потенціалу у зв’язку з тим, що маркетинговий потенціал $є$ ресурсом, що здатен втрачати свої якості або набувати їх в нових інтерпретаціях, та може ніколи не повернутися до попереднього стану. Саме тому, ми вважаємо за доцільне визначити динамічність як основну характеристику маркетингового потенціалу.

Аналіз вищезазначених трактувань маркетингового потенціалу наводить на думку, що недостатньо уваги приділяється саме латентній складовій маркетингового потенціалу, яка є головною характеристикою можливостей організації. Ми вважаємо, що доцільно при формуванні теоретичної бази дослідження маркетингового потенціалу виділяти латентну складову, розкриття якої відбувається під час розумової діяльності персоналу та пошуку інформації про невикористанні можливості.

Таким чином, аналіз наукової літератури дозволив звести трактування поняття маркетингового потенціалу до чотирьох підходів (циклічний, системний, синергійний, динамічний) та доповнити їх інформаційним підходом, який, на нашу думку, найбільш точно розкриває сутність даного поняття в період панування економіки знань (Табл.2).

Таблиця 2

Сутність підходів до дослідження маркетингового потенціалу

\begin{tabular}{|c|c|}
\hline Підхід & Сутність \\
\hline Циклічний & $\begin{array}{c}\text { сукупність латентних та наявних компонентів системи, які в процесі } \\
\text { діяльності організації проходять цикл від ідентифікації до виведення } \\
\text { з експлуатації }\end{array}$ \\
\hline Системний & $\begin{array}{c}\text { дослідження маркетингового потенціалу як сукупності компонентів } 3 \\
\text { урахуванням зв’язків, які виникають між компонентами в процесі } \\
\text { діяльності організації }\end{array}$ \\
\hline Синергійний & $\begin{array}{c}\text { самоорганізація маркетингового потенціалу через посилення ефекту } \\
\text { від одночасного сполучення всіх компонентів }\end{array}$ \\
\hline Динамічний & $\begin{array}{c}\text { сукупність латентних та виявлених компонентів, які мають } \\
\text { обмежений у часі ефект від використання та здатні змінювати свої } \\
\text { якісні та кількісні характеристики під впливом зовнішніх та } \\
\text { внутрішніх імпульсів }\end{array}$ \\
\hline Інформаційний & $\begin{array}{c}\text { накопичені знання про стан маркетингового потенціалу організації, } \\
\text { які можуть бути реалізовані як можливості збалансованого розвитку } \\
\text { всіх складових системи у поточному та довгостроковому періоді }\end{array}$ \\
\hline
\end{tabular}

Звернемо увагу на те, що дослідження щодо сутності маркетингового потенціалу закладів вищої освіти дозволили виокремити в його структурі ключові ресурси як основні складові маркетингового потенціалу, які організація вважає перевагами на ринку надання освітніх послуг. Отже, під ключовими ресурсами маркетингового 
потенціалу ми розуміємо аспекти маркетингового потенціалу, які проєктуються на напрямки діяльності закладу вищої освіти та є зосередженням латентних та виявлених можливостей розвитку, досягненням економічного ефекту від їх використання та підвищенням рівня конкурентоспроможності.

Маркетинговий потенціал для різних галузей економіки може диференціюватись за своїми складовими в силу особливостей середовищ, в яких вони функціонують. Водночас глибинна сутність та позитивний ефект від його якісного використання та формування в будь-яких сферах господарювання залишається незмінним.

В складі кожного ключового ресурсу маркетингового потенціалу закладу вищої освіти ЗВО є критерії, за якими можливо здійснити аналіз, оцінку, характеристику маркетингового потенціалу за конкретним напрямком його розгалуження. Пропонуємо такі критерії називати компонентами. Отже, під компонентами маркетингового потенціалу закладу вищої освіти ЗВО слід розуміти структурні одиниці маркетингового потенціалу 3ВО, які впорядковані за напрямками діяльності внаслідок спільних цілей функціонування.

Внаслідок того, що ЗВО диференційовані за рівнем маркетингового потенціалу та мають в своєму арсеналі різні ключові ресурси, доцільним буде виділити найбільш спільні напрямки уособлень маркетингового потенціалу ЗВО, тобто з'ясувати його структуру (рис.1).

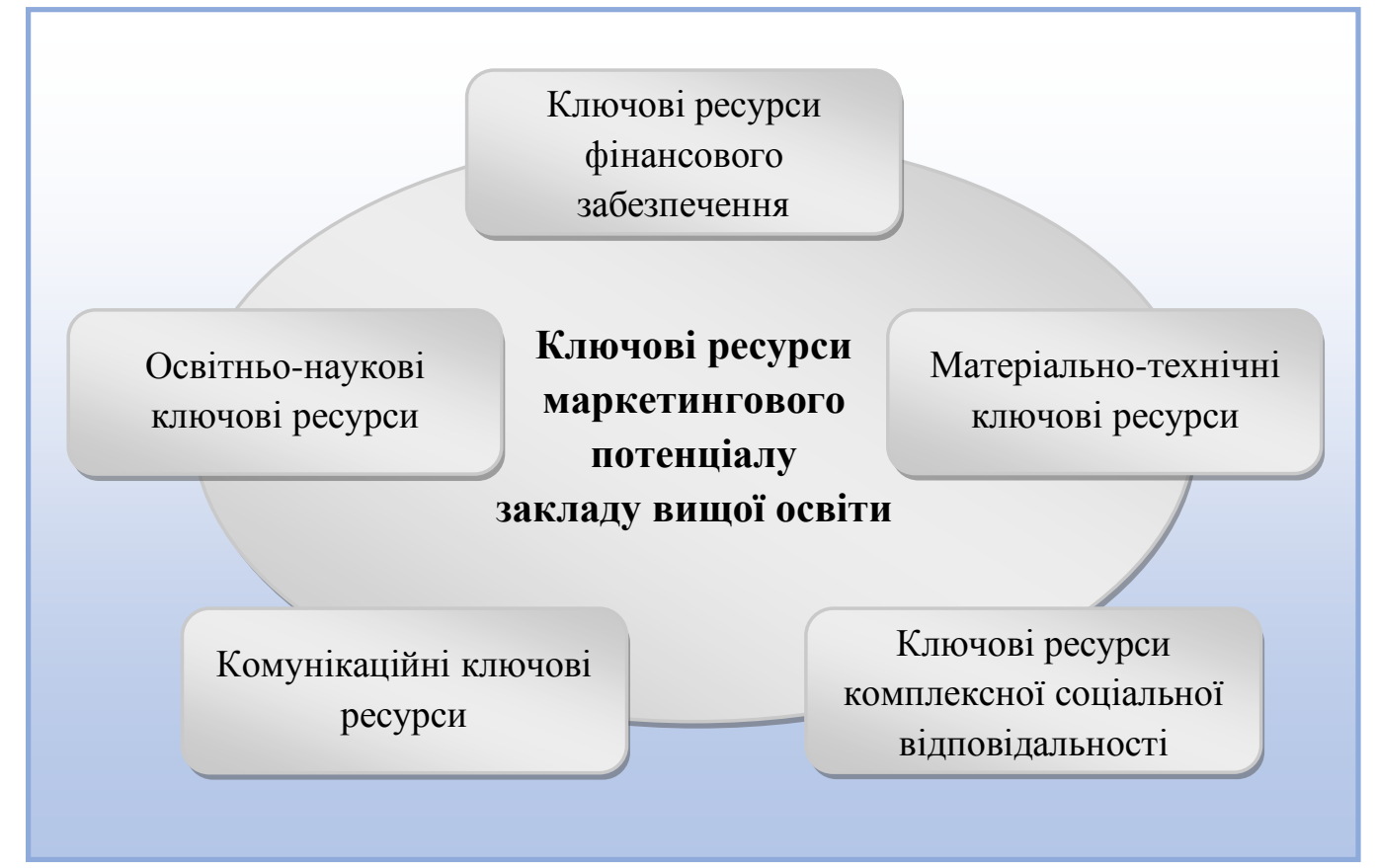

* розробка автора

Рисунок 1. Ключові ресурси маркетингового потенціалу 3ВО

На нашу думку, найбільш універсально ключові ресурси маркетингового потенціалу ЗВО можна представити як:

Ключові ресурси фінансового забезпечення - спроможність залучати та ефективно використовувати фінансові ресурси ЗВО для досягнення цілей функціонування; 
Освітньо-наукові ключові ресурси - потенціал якісної організації і надання освітніх та наукових послуг, що проектується на міжнародні та вітчизняні рейтинги 3BO;

Комунікаційні ключові ресурси - можливості встановлення взаємин з цільовою аудиторією за всіма можливими каналами зв'язку, спроможність знаходити необхідну та достовірну інформацію; здатність раціонально керувати ціноутворенням на платні послуги ЗВО;

Матеріально-технічні ключові ресурси - наявність необхідної матеріальнотехнічної бази забезпечення освітнього та наукового процесу та практичного відпрацювання умінь та навичок отриманих в результаті навчання;

Ключові ресурси комплексної сочіальної відповідальності - потенціал створення належного забезпечення освітнього процесу для всіх категорій громадян, різного віку та статусу; організація благодійних заходів та формування екологічної свідомості 3 подальшим поширення iii положень як всередині організації так i за іiі межами; створення сприятливих умов для роботи співробітників та їх мотивації.

Узагальнюючи проведене дослідження, пропонуємо трактувати поняття маркетингового потенціалу закладів вищої освіти з наступних позицій та виокремити його основні характеристики (рис.2):

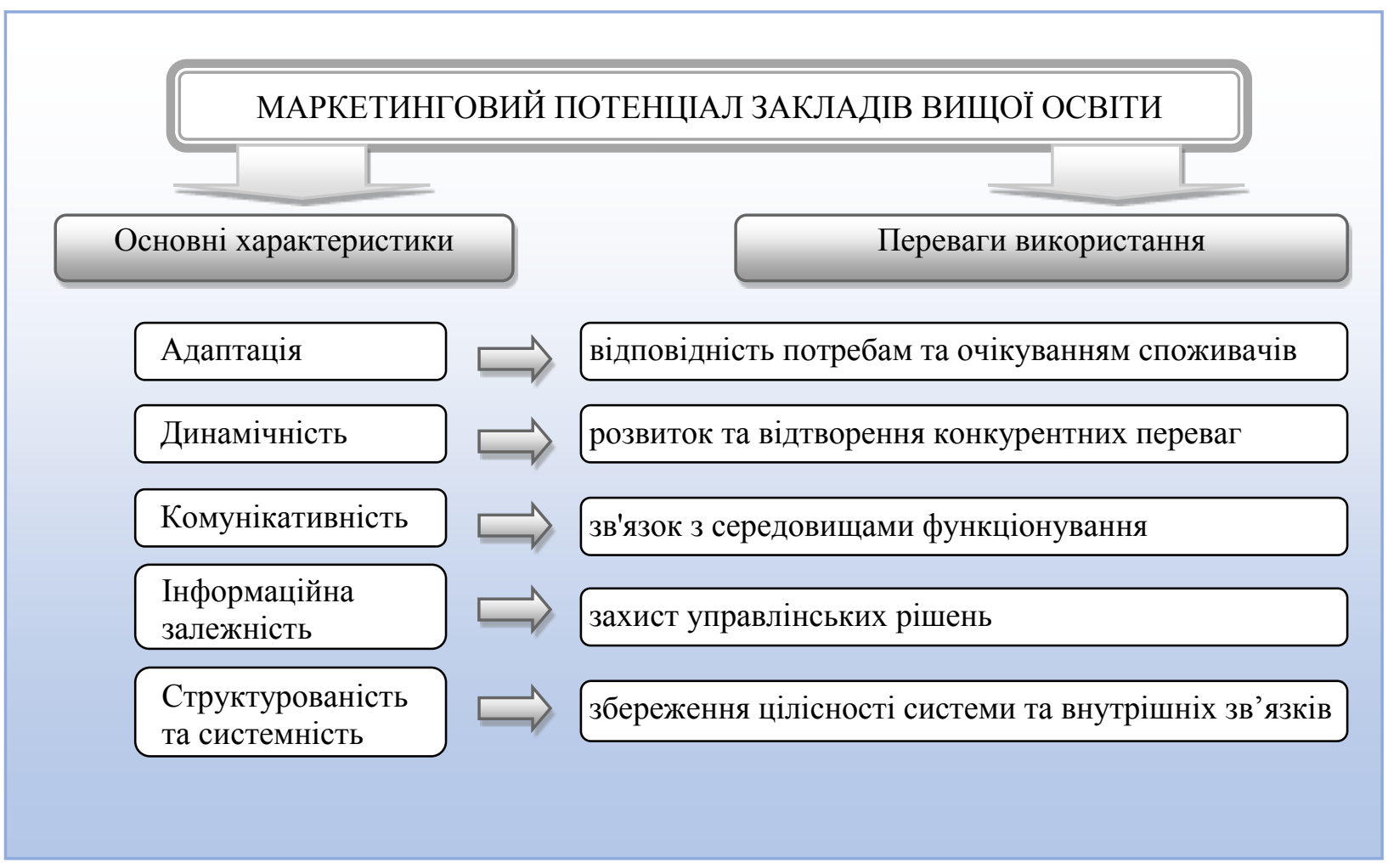

* розробка автора

1 - як сукупність ключових ресурсів, що складаються з латентних та виявлених компонентів, що схильні до зміни своїх властивостей у зв'язку та відповідно 3 коливаннями потреб ринку освітніх послуг, ринку праці та економіки загалом. 
2 - як інформація про стан компонент ключових ресурсів маркетингового потенціалу закладу вищої освіти, що використовується при прийнятті управлінських рішень та вибору вектору розвитку та діяльності організації.

3 - як сукупність взаємопов'язаних ресурсів, які утворюють підсистему маркетингового потенціалу з притаманним їй синергійним ефектом, що проявляється внаслідок одночасного функціонування ключових ресурсів маркетингового потенціалу та відкарбовується на спроможності даної системи досягати поставлених цілей.

Наявність маркетингового потенціалу в кожному ЗВО передбачає заходи щодо ефективного розвитку його складових для отримання максимального економічного ефекту. Розвиток є одним 3 напрямків реалізації загальної системи управління та дозволяє досягати основних завдань та цілей діяльності організації у відповідності до очікувань зовнішнього середовища. На думку І.Поліщук, «цілеспрямоване управління маркетинговим потенціалом дозволяє підприємству побудувати довгострокові i ефективні відносини із споживачами і сформувати лояльну цільову аудиторію компанії $[15$, c. 98$] »$.

Отже, виокремлення ключових ресурсів маркетингового потенціалу ЗВО з метою подальшого розвитку передбачає дотримання законів, які діють в організації та визначення закономірностей іiі роботи 3 метою запобіганню руйнівного впливу на цілісність ЗВО як системи в результаті досягнення завдань розвитку маркетингового потенціалу.

Запропонована концепція розвитку маркетингового потенціалу враховує особливості функціонування 3ВО та 3 метою виконання завдань концепції використовує закономірності й принципи розвитку маркетингового потенціалу закладів вищої освіти, які було обгрунтовано в роботах [16,17]. Запропоновані принципи, на нашу думку, доцільно згрупувати за суттєвими напрямками розвитку маркетингового потенціалу 3ВО, а саме виділити: універсальні - характерні для будь-якої організації; фінансові - визначають характер роботи з фінансовими ресурсами; людиноорієнтовані направлені на розвиток та задоволення потреб особистості; інформаційні - визначають інформаційні засади розвитку.

Отже, теоретичною базою концепції розвитку маркетингового потенціалу ЗВО виступає: визначення мети, завдань, ключових ресурсів, принципів розвитку маркетингового потенціалу ЗВО.

Практичну реалізацію запропонованої концепції забезпечує використання бенчмаркінгу як інструменту розвитку маркетингового потенціалу ЗВО. Аналіз наукових джерел та поглядів щодо визначення сутності бенчмаркінгу узагальнено в роботі [17]. Проведена робота дозволила сформувати власне бачення трактування даного поняття та запропонувати визначення бенчмаркінгу як інструменту розвитку, завданням якого $є$ безперервна розробка заходів щодо адаптації та імплементації в роботу організації найкращого ринкового досвіду ведення конкурентної боротьби 3 метою вдосконалення функціонування організації та досягнення позитивних економічних наслідків.

Використання бенчмаркінгу в розвитку маркетингового потенціалу ЗВО передбачає доповнення теоретичного підгрунтя в даному напрямку досліджень та обгрунтування функцій, які виникають при застосуванні додаткового інструменту бенчмаркінгу в реалізації функцій розвитку.

Отже, важливим структурним елементом концепції розвитку маркетингового потенціалу 3ВО на засадах бенчмаркінгу є функції, які поділяються на класичні та функції бенчмаркінгу [18]. Класичні функції - це функції, які виконує розвиток 
маркетингового потенціалу відносно маркетингового потенціалу як об'єкту розвитку, в той час як функції бенчмаркінгу - це додатковий функціонал розвитку маркетингового потенціалу 3ВО, який виникає при використанні інформації, отриманої внаслідок проведення бенчмаркінгу.

Використання бенчмаркінгу в розвитку маркетингового потенціалу ЗВО вимагає вирішення питання практичного підгрунтя його впровадження та використання. У зв'язку з тим, що інструмент бенчмаркінгу в системі закладів вищої освіти ще не набув такої популярності як в деяких закордонних 3ВО, доцільним буде запропонувати комплексний механізм розвитку маркетингового потенціалу ЗВО на засадах бенчмаркінгу як ключовий блок практичної частини реалізації концепції.

Комплексний механізм розвитку дозволить вирішити завдання за трьома напрямками, які доцільно звести до механізмів, покликаних виконати організаційні зміни, задовольняти очікування споживачів освітніх послуг на емоційному та фізичному рівнях, забезпечити в результаті економічний ефект та розширити канали фінансового забезпечення розвитку. Отже, для досягнення мети концепції розвитку маркетингового потенціалу закладів вищої освіти слід виділити наступні механізми в складі комплексного та завдання, покладені на них:

- організаційний механізм - окреслення мети та очікуваних результатів; визначення необхідної чисельності та складу працівників; закріплення функцій та відповідальності; розмежування повноважень; проведення навчальних тренінгів; закріплення обов'язків і прав в положеннях та функціональних обов'язках; подолання перешкод, пов'язаних з впровадженням бенчмаркінгу на організаційному рівні, вибір стратегіï;

- гендерно-поведінковий механізм - визначення потреб цільової аудиторії; розмежування емоційних та поведінкових потреб; використання гендерного підходу в управлінні; вивчення поведінки споживачів в різних умовах; дослідження мотивів прийняття економічних рішень споживачами освітніх послуг; врахування потреб співробітників;

- фінансово-економічний механізм - аналіз фінансового стану; пошук додаткових джерел надходжень; планування розподілу видатків; забезпечення стійкого фінансового стану; збільшення надходжень коштів; запобігання виникненню заборгованості за надання платних послуг; формування важелів впливу на подолання нецільового використання коштів в ЗВО; матеріальна мотивація; виділення компонент маркетингового потенціалу та їх розвиток; раціональне та ефективне використання наявних компонент ключових ресурсів маркетингового потенціалу ЗВО; стимулювання пошуку нових компонент маркетингового потенціалу; статистичний аналіз складових маркетингового потенціалу; розробка проектів впровадження досвіду отриманого внаслідок проведення бенчмаркінгу; ціноутворення; вибір додаткових методів розвитку маркетингового потенціалу; аналіз факторів впливу на стан ЗВО та склад ключових ресурсів маркетингового потенціалу; прогнозування стану результативних показників внаслідок реалізації концепції розвитку маркетингового потенціалу на засадах бенчмаркінгу.

Таким чином, можна констатувати, що спрямованість механізмів дозволяє реалізувати завдання запропонованої концепції. В той самий час, провідна роль в комплексному механізмі приходиться на фінансово-економічний аспект, адже завдання, які входять в його компетенцію, дозволяють досягти економічного ефекту, який переслідують майже всі організації. 
Обгрунтування концепції передбачає визначення бажаних результатів від використання бенчмаркінгу в розвитку маркетингового потенціалу, що виражається в досягненні:

- економічного ефекту як наслідку якісного розвитку маркетингового потенціалу, що підкарбовується на збільшенні чисельності абітурієнтів, формуванні позитивного іміджу, підвищення якості освітньої складової процесу, попиту на ЗВО як на роботодавця, можливості участі у грантах та залученні донорів шляхом залучення компетентних фахівців та інше.

- конкурентного становища на ринку освітніх послуг;

- можливостей розкриття та використання латентного маркетингового потенціалу;

- організаційних зміни, спрямованих на досягнення якісного розвитку маркетингового потенціалу на засадах бенчмаркінгу;

- соціального позитивного ефекту, який розкривається у всебічному розвитку особистості та врахуванні її потреб при роботі або навчанні в ЗВО.

Узагальнюючи вищезазначене, пропонуємо концепцію розвитку маркетингового потенціалу 3ВО на засадах бенчмаркінгу як базис підвищення конкурентоспроможності освітнього простору на всіх його рівнях (рис.3).

Додатково слід зазначити, що важливим в реалізації розробленої концепції $\epsilon$ подолання перешкод впровадження бенчмаркінгу, які описані в роботі [19]. У зв'язку з тим, що існування теоретичного підгрунтя використання бенчмаркінгу в розвитку маркетингового потенціалу ЗВО мало підкріплено практикою вітчизняного досвіду, керівництво може стикнутися 3 труднощами використання запропонованого інструменту. В даному випадку доцільним буде виявлення характеру перешкод впровадження та поступового введення в дію бенчмаркінгу як інструменту розвитку.

Таким чином, запропонована концепція розвитку маркетингового потенціалу ЗВО на засадах бенчмаркінгу $є$ гнучкою до змін зовнішнього та внутрішнього середовища, інтегрованою в загальну систему функціонування 3ВО та націленою на формування необхідного теоретично-методологічного підгрунтя зазначеного напрямку розвитку.

Висновки. Концепція розвитку маркетингового потенціалу ЗВО на засадах бенчмаркінгу дозволяє досягти бажаних цілей всіх ЗВО: збільшити чисельність абітурієнтів, бути затребуваним на ринку освітніх послуг та мати можливість вибирати кращих з найкращих як з числа вступників так і з числа співробітників.

Концепція має в своїй структурі складові, реалізація яких забезпечує виконання завдань на кожному 3 рівнів розвитку маркетингового потенціалу. Усвідомлення необхідності використання розвитку маркетингового потенціалу ЗВО та бенчмаркінгу суб'єктами освітнього середовища дозволить швидше досягти бажаного рівня конкурентоспроможності на ринку освітніх послуг.

Додатково слід зазначити, що важливим в реалізації розробленої концепції $€$ подолання перешкод впровадження бенчмаркінгу, які описані в роботі [19]. У зв'язку з тим, що існування теоретичного підгрунтя використання бенчмаркінгу в розвитку маркетингового потенціалу ЗВО мало підкріплено практикою вітчизняного досвіду, керівництво може стикнутися 3 труднощами використання запропонованого інструменту. В даному випадку доцільним буде виявлення характеру перешкод впровадження та поступового введення в дію бенчмаркінгу як інструменту розвитку.

Таким чином, запропонована концепція розвитку маркетингового потенціалу ЗВО на засадах бенчмаркінгу є гнучкою до змін зовнішнього та внутрішнього середовища, інтегрованою в загальну систему функціонування 3ВО та націленою на формування необхідного теоретично-методологічного підгрунтя зазначеного напрямку розвитку. 
Висновки. Концепція розвитку маркетингового потенціалу ЗВО на засадах бенчмаркінгу дозволяє досягти бажаних цілей всіх ЗВО: збільшити чисельність абітурієнтів, бути затребуваним на ринку освітніх послуг та мати можливість вибирати кращих з найкращих як з числа вступників так і з числа співробітників.

Концепція має в своїй структурі складові, реалізація яких забезпечує виконання завдань на кожному 3 рівнів розвитку маркетингового потенціалу. Усвідомлення необхідності використання розвитку маркетингового потенціалу ЗВО та бенчмаркінгу суб'єктами освітнього середовища дозволить швидше досягти бажаного рівня конкурентоспроможності на ринку освітніх послуг.

\section{СПИСОК ВИКОРИСТАНИХ ДЖЕРЕЛ}

1. Антикризове управління національною економікою:монографія / I. Малий. та ін. Київ:КНЕУ, 2017. 368 с.

2. Завадський Й. С., Осовська Т. В., Юшкевич О. О. Економічний словник. Київ : Кондор, 2006. 356 с.

3. Ващенко Н. В. Обгрунтування концепції управління розвитком підприємства. Академічний огляд. 2014. № 1(40). С. 94-102.

4. Большой энциклопедический словар : веб-сайт. URL: https://gufo.me/search?term=\%D0\%BA\%D0\%BE\%D0\%BD\%D1\%86\%D0\%B5\%D0\%B F\%D1\%86\%D0\%B8\%D1\%8F (дата звернення 29.11.2020).

5. Корваленко М., Сікало М. Запровадження Концепції розвитку ринку зерна України. Публічне управління та адміністрування. 2019. № 2(20). С. 73-78.

6. Вікіпедія. Вільна енциклопедія : веб-сайт. URL: http://uk.wikipedia.org/ wiki/Концепція (дата звернення 29.11.2020).

7. Барна С.С. Концепція управління інноваційним розвитком енергосервісних підприємств. Інноваиійна економіка. 2020. № 3-4 (83). C.71-77. DOI: 10.37332/23091533.2020.3-4.10

8. Банзелюк І. В. Рівні управління маркетинговим потенціалом закладів вищої освіти. Розвиток форм $і$ методів сучасного менеджменту в умовах глобалізації: VIII наук.-практ. конф., 02-06 листопада 2020 р. м. Дніпро: Дніпровський державний аграрно-економічний університет, 2020.

9. Дороніна О.А. Роль наукової діяльності студента у формуванні компетенцій сучасного фахівця в сфері економіки та управління. Економіка $i$ організація управління. 2017. № 4. С. 207-215.

10. Іваненко В., Ковальчук О. Оцінка маркетингового потенціалу підприємства: компаративний аналіз наукових підходів. «Вісник ЖДТУ»: Економіка, управління та адміністрування. 2019. № 1(87). С. 72-82.

11. Маматова Л.Ш. Місце маркетингового потенціалу в системі фінансовоінвестиційного потенціалу підприємств. Теоретичні і практичні аспекти економіки та інтелектуальної власності. 2017. Вип. 15. С. 140-145.

12. Кунев С.В., Е.Н. Мальченков Маркетинговый потенциал фармацевтических производителей: сущность и тенденции развития. Регионология. 2012. № 1 (78). С. 139-143.

13. Родионова А.П. Оценка и реализация маркетингового потенциала развития машиностроительных предприятий региона. Регионология. 2009. № 3. URL: http://regionsar.ru/ru/node/375 (дата звернення 29.11.2020).

14. Баранчеев В. П. Анализ и оценка маркетингового потенциала. Маркетинг. 2004. № 3. C. $42-50$. 


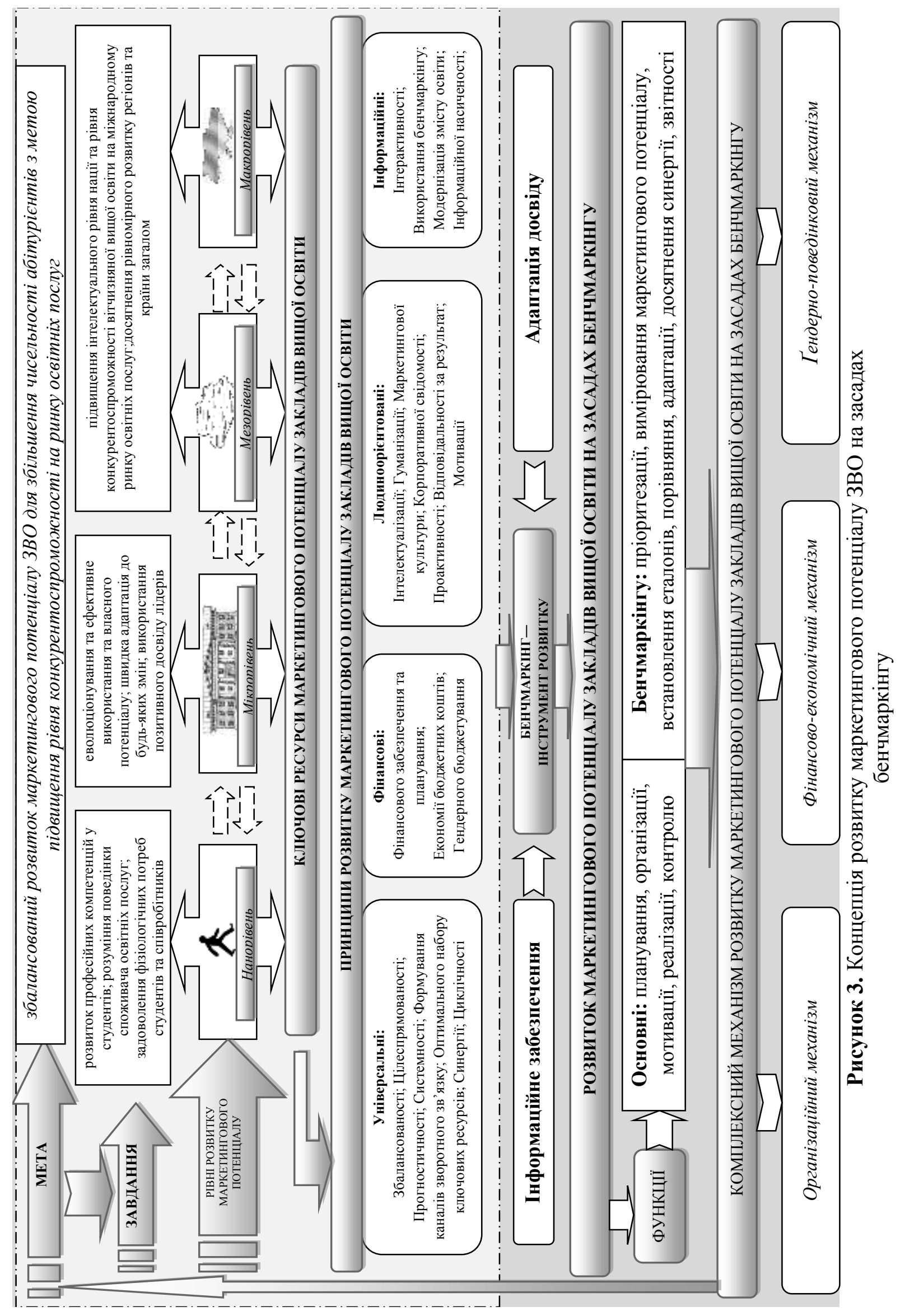


15. Поліщук I.I. Фактори розвитку маркетингового потенціалу підприємства. Науковий вісник Полісся. 2016. Вип. 2. С. 97-102.

16. Снісарчук І.В. Закономірності управління маркетинговим потенціалом закладів вищої освіти. Вісник Житомирського державного технологічного університету. Серія: економіка, управління та адміністрування. 2019. №3 (89). С.87-93.

17. Банзелюк І.В. Принципи управління маркетинговим потенціалом закладів вищої освіти. Економіка і організаџія управління. 2019. №3 (35). С.101-110.

18. Снісарчук I.В. Сутність та види бенчмаркінгу маркетингового потенціалу закладів вищої освіти. Міжнародний науковий журнал "Інтернаука". Серія: "Економічні науки". 2019. №7. С. 40-50. https://doi.org/10.25313/2520-2294-2019-7-5129

19. Банзелюк I. Функції управління маркетинговим потенціалом закладів вищої освіти на засадах бенчмаркінгу. Сучасний менеджмент: тенденції, проблеми та перспективи розвитку: V міжн. наук.практ. конф. 23 квітня 2020 р. Дніпро: Університет імені Альфреда Нобеля, 2020. С. 25-26.

20. Ахновська I. О., Банзелюк I. В. Переваги та перешкоди використання бенчмаркінгу в управлінні маркетинговим потенціалом закладів вищої освіти. Modern Economics. 2020. № 20(2020). C. 20-25.: https://doi.org/10.31521/modecon.V20(2020)-03

\section{REFERENCE}

1. Malyj, I. (2017). Antykryzove upravlinnja nacionaljnoju ekonomikoju:monoghrafija. Kyjiv:KNEU [in Ukrainian].

2. Zavadskyi, Y.S., Osovska, T.V. \& Yushkevych, O.O. (2006,) Ekonomichnyi slovnyk, Kondor, Kyiv, Ukraine, 356 p. [in Ukrainian].

3. Vashchenko, N.V. (2014), Substantiation of enterprise development management concept" Akademichnyi ohliad, 1(40), 94-102 [in Ukrainian].

4. Large encyclopedic dictionary (2020). Retrieved from https://gufo.me/search?term=\%D0\%BA\%D0\%BE\%D0\%BD\%D1\%86\%D0\%B5\%D0\%B F\%D1\%86\%D0\%B8\%D1\%8F [in Rus.].

5. Korvalenko, M. \& Sikalo, M. (2019), Introduction of Ukraine grain market development Concept, Publichneupravlinnia ta administruvannia, 2(20), 73-78 [in Russian].

6. Wikipedia. Free encyclopedia (2020) Retrieved from http://uk.wikipedia.org/ wiki/Концепція [in Ukr.]

7. Barna, S.S. (2020) The concept of management of innovative development of energy service enterprises. Innovatsijna ekonomika, 3-4(83), 71-77. doi: 10.37332/23091533.2020.3-4.10

8. Banzeljuk, I.V. (2020). Levels of management of marketing potential of higher education institutions. [Conference Proceedings of the International Economic Conference], Mizhnarodna Ekonomichna konferentsiya [International economic conference]. Dnipropetrovsk : Dnipro State Agrarian and Economic University [in Ukrainian].

9. Doronina, O.A. (2017). The role of the student's scientific activity in the formation of the competencies of a modern specialist in the field of economics and management. Ekonomika i orghanizacija upravlinnja, 4, 207-215 [in Ukrainian].

10. Ivanenko, V. \& Kovaljchuk, O. (2019). Assessment of marketing potential of the enterprise: a comparative analysis of scientific approaches. Visnyk ZhDTU: Ekonomika, upravlinnja ta administruvannja, 1(87), 72-82 [in Ukrainian].

11. Mamatova, L.Sh. (2017). The place of marketing potential in the system of financial and investment potential of enterprises. Teoretychni $i$ praktychni aspekty ekonomiky ta intelektual'noi' vlasnosti, zbirnyk naukovyh prac', 15, 140-145 [in Ukrainian]. 
12. Kunev, S.V. \& Mal'chenkov, E.N. (2012), Marketing potential of pharmaceutical manufacturers: the essence and trends. Regionologiya, 1, 139-143 [in Ukrainian].

13. Rodionova, A.P. (2009), Assessment and implementation of marketing potential for the development of machine-building enterprises in the region. Regionologiya, 3. Retrieved from http://regionsar.ru/ru/node/375[in Ukrainian].

14. Barancheev, V. P. (2004) Analysis and evaluation of marketing potential. Marketing,3, 42-50 [in Ukrainian].

15. Polishhuk, I.I. (2016). Factors of development of marketing potential of the enterprise. Naukovyj visnyk Polissja, Vol. 2, 97-102 [in Ukrainian].

16. Snisarchuk, I.V. (2019). Regularities of marketing potential management of higher education institutions. Visnyk Zhytomyrsjkogho derzhavnogho tekhnologhichnogho universytetu. Serija: ekonomika, upravlinnja ta administruvannja, 3 (89), C.87-93 [in Ukrainian].

17. Banzeljuk, I.V. (2019). Principles of management of marketing potential of higher education institutions. Ekonomika i orghanizacija upravlinnja, №3 (35), 101-110 [in Ukrainian].

18. Snisarchuk, I.V. (2019) Essence and types of benchmarking marketing potential of higher education institutions. Mizhnarodnyj naukovyj zhurnal "Internauka". Seriia: "Ekonomichni nauky", 7, 40-50 [in Ukrainian].

19. Banzeljuk, I. (2020) Functions of managing the marketing potential of higher education institutions on the basis of benchmarking. Zbirka dopovidej na Mizhnarodnij ekonomichnij konferentsii [Conference Proceedings of the International Economic Conference], Mizhnarodna Ekonomichna konferentsiya [International economic conference]. Dnipropetrovsk: Alfred Nobel University [in Ukrainian].

20. Akhnovsjka, I. \& Banzeliuk, I. Advantages and obstacles of using benchmarking in managing. Modern Economics, 20(2020), 20-25. DOI: https://doi.org/10.31521/modecon.V20(2020)-03

Банзелюк И.В., аспирантка, Донецкий национальный университет имени Васыля Стуса, ORCID: 00000002-0266-0569

i.snisarchuk@donnu.edu.ua

\section{КОНЦЕПЦИЯ РАЗВИТИЯ МАРКЕТИНГОВОГО ПОТЕНЦИАЛА УЧРЕЖДЕНИЙ ВЫСШЕГО ОБРАЗОВАНИЯ НА ОСНОВЕ БЕНЧМАРКИНГА}

В статье обоснованы концептуальные положения развития маркетингового потенциала учреждений высшего образования на основе бенчмаркинга. Определены составляющие разработанной концепции. Предложено развитие маркетингового потенциала учреждений высшего образования на уровнях его формирования, а именно на наноуровне, микроуровне, мезоуровне и макроуровне и определены задачи реализации концепции на каждом из уровней. Определены ключевые функции, которые возлагаются на систему развития маркетингового потенциала учреждений высшего образования при использовании бенчмаркинга как инструмента развития. Предложено осуществлять их разделение на классические функции и функции бенчмаркинга. Разработан комплексный механизм развития маркетингового потенциала учреждений высшего образования на основе бенчмаркинга, который позволит достичь цуели предложенной концепщии за счет синергии трех составляющих: организащионного, финансовоэкономического и гендерно-поведенческого механизма. На основании проведенного исследования обозначень особенности конщепции развития маркетингового потенциала ЗВО на основе бенчмаркинга и указано ожидаемые результаты от реализации в образовательном пространстве.

Ключевые слова: маркетинговый потенциал, развитие, учреждение выстего образования, бенчмаркинг, уровни развития, концепџия развития маркетингового потенџиала. 
I.Banzeliuk, postgraduate student, Vasyl`Stus Donetsk National University, ORCID: 0000-0002-0266-0569 i.snisarchuk@donnu.edu.ua

\section{CONCEPT OF THE DEVELOPMENTOF THE MARKETING POTENTIAL OF HIGHER EDUCATION INSTITUTIONS ON THE BASIS OF BENCHMARKING}

The article substantiates the conceptual provisions of the development the marketing potential of higher education institutions based on benchmarking. The components of the developed concept are outlined. The development of the marketing potential of higher education institutions at the levels of its formation, namely at the nano-level, micro-level, meso-level and macro-level, is proposed, and the tasks of implementing the concept at each of the levels are defined.The key functions that are assigned to the marketing potential development system of higher education institutions when using benchmarking as a management tool are identified.It is proposed to divide them into classical functions and benchmarking functions. A comprehensive mechanism for developing the marketing potential of higher education institutions based on benchmarking has been developed, which will allow achieving the goal of the proposed concept due to the synergy of three components: organizational, finance-economic and gender-behavioral mechanisms. Based on the conducted research, the features of the concept of developing the marketing potential of higher education institutions based on benchmarking are outlined and the expected results from its implementation in the educational space are indicated.

Keywords: marketing potential, development, higher education institution, benchmarking, levels of development, the concept of marketing potential development. 